Vol 1. No. 4, Oktober 2021 P-ISSN : 2774-8030, e-ISSN : 2774-8030

\title{
PENERAPAN KEGIATAN EKSPERIMEN DALAM PEMBELAJARAN IPA UNTUK MENINGKATKAN MOTIVASI DAN HASIL BELAJAR SISWA
}

\author{
KARTININGSIH \\ SMP Negeri 1 Sugihwaras \\ e-mail: kartinabilah@gmail.com
}

\begin{abstract}
ABSTRAK
Tujuan penelitian ini adalah untuk meningkatkan motivasi dan hasil belajar siswa melalui penerapan kegiatan eksperimen dalam pembelajaran IPA pada siswa SMP Negeri 1 Sugihwaras. Subyek penelitian adalah 32 siswa kelas VIII C SMP Negeri 1 Sugihwaras Bojonegoro. Berdasarkan pengalaman guru selama mengajar di kelas VIII C SMPN 1 Sugihwaras Bojonegoro, pada umumnya siswa dalam belajar hanya membaca tanpa memahami isi pelajaran. Siswa kurang terlatih untuk berfikir, menyampaikan ide dan menyelesaikan masalah. Pada setiap kegiatan pembelajaran IPA siswa cenderung pasif, kurang bersemangat dan sulit untuk aktif bertanya maupun menyampaikan pendapatnya serta kurang bisa bertanggungjawab terhadap tugasnya. Dalam kegiatan pembelajaran sering tampak motivasi siswa saat belajar IPA masih rendah sehingga hal ini berpengaruh terhadap hasil belajar siswa. Penelitian ini dilaksanakan dengan rancangan penelitian tindakan kelas dengan prosedur pelaksanaannya mengikuti prinsip dasar penelitian tindakan yang umum. Adapun Langkahlangkah penelitian tindakan kelas terdiri dari tahap perencanaan, pelaksanaan tindakan, observasi dan refleksi. Pelaksanaan penelitian ini dilaksanakan sebanyak dua siklus. Hasil penelitian menunjukkan adanya peningkatan dari siklus pertama ke siklus kedua. Data hasil penelitian menunjukkan bahwa semua indikator mengalami peningkatan keberhasilan sesuai dengan yang diharapkan baik pada siklus pertama maupun siklus kedua.
\end{abstract}

Kata Kunci: Kegiatan eksperimen, motivasi, hasil belajar siswa

\section{PENDAHULUAN}

llmu Pengetahuan Alam berhubungan dengan cara mencari tahu tentang alam secara sistematis, sehingga Ilmu Pengetahuan Alam bukan hanya penguasaan kumpulan pengetahuan yang berupa fakta, konsep, atau prinsip-prinsip saja, tetapi juga merupakan suatu proses penemuan. Permendiknas no. 22 tahun 2006 tentang Standar Kompetensi dan Kompetensi Dasar Kurikulum Tingkat Satuan Pendidikan, menjelaskan bahwa IPA berkaitan dengan cara memahami alam secara sistematis, sehingga IPA bukan hanya sebatas penguasaan kumpulan pengetahuan (produk ilmu) yang berupa fakta-fakta, konsep-konsep, atau prinsip-prinsip saja, tetapi lebih sebagai proses penemuan. Pembelajaran IPA diharapkan dapat menjadi wahana bagi siswa untuk mempelajari diri sendiri dan lingkungannya, serta prospek pengembangan lebih lanjut dengan menerapkannya dalam kehidupan sehari-hari. Proses pembelajaran IPA hendaknya menekankan pada pemberian pengalaman langsung untuk mengembangkan kompetensi melakukan dan memahami alam secara ilmiah. Pembelajaran IPA diarahkan pada inkuiri dan berbuat sehingga dapat membantu siswa untuk memperoleh pemahaman yang lebih bermakna tentang alam sekitar.

Menurut Peter Kline dalam Angkowo dan Kosasih (2007:49), belajar akan efektif jika dilakukan dalam suasana menyenangkan (fun and enjoy). Maka perlu diciptakan suasana dan kondisi belajar yang kondusif, selain faktor lain yang ikut menentukan hasil belajar siswa. Salah satu faktor yang mempengaruhi adalah faktor pengajar. Oleh sebab itu, mengajar yang diartikan sebagai suatu usaha menciptakan sistem lingkungan, harus memungkinkan terjadinya proses pembelajaran yang menyenangkan. Tetapi perlu diketahui pula bahwa sistem lingkungan ini pun dipengaruhi oleh berbagai komponen yang saling berinteraksi, antara lain, tujuan pembelajaran, bahan kajian yang disampaikan, guru, siswa, jenis kegiatan yang dikembangkan, metode serta media pembelajaran yang dipilih. 
Dengan metode dan media yang tepat diharapkan seorang pengajar mampu mendorong siswa untuk belajar secara aktif, giat, mandiri dan cerdas sehingga mendapatkan hasil belajar yang maksimal. Selain itu juga dengan metode dan strategi yang tepat seorang pengajar bisa menciptakan suasana belajar yang tidak membosankan, tetapi justru menjadi sebuah kegiatan yang sangat menyenangkan dan berhasil guna.

Berdasarkan pengalaman guru selama mengajar di kelas VIII C SMPN 1 Sugihwaras Bojonegoro, pada umumnya siswa dalam belajar hanya membaca tanpa memahami isi pelajaran. Siswa kurang terlatih untuk berfikir, menyampaikan ide dan menyelesaikan masalah. Pada setiap kegiatan pembelajaran IPA siswa cenderung pasif, kurang bersemangat dan sulit untuk aktif bertanya maupun menyampaikan pendapatnya serta kurang bisa bertanggungjawab terhadap tugasnya. Dalam kegiatan pembelajaran sering tampak motivasi siswa saat belajar IPA masih rendah. Hal ini bisa dilihat dari pengamatan terhadap proses pembelajaran sehari-hari, hanya $20 \%$ siswa aktif bertanya atau menyampaikan pendapatnya saat kegiatan pembelajaran. sedangkan $80 \%$ siswa pasif, hanya mendengarkan dan menulis apa yang disampaikan oleh guru. Bahkan saat siswa diminta oleh guru untuk mempresentasikan hasil pekerjaannya hanya $25 \%$ siswa yang mampu dan berani mengkomunikasikan hasil pekerjaannya.

Berdasarkan permasalahan tersebut, guru yang selanjutnya bertindak sebagai peneliti bersama dengan guru IPA yang lain melakukan diskusi terhadap proses pembelajaran IPA yang selama ini dilakukan di kelas VIII C SMPN 1 Sugihwaras Bojonegoro. Hasil diskusi kami simpulkankan bahwa siswa kelas VIII C SMPN 1 Sugihwaras Bojonegoro kurang termotivasi dalam belajar IPA sehingga penguasaan terhadap materi juga rendah. Hal ini bisa dilihat dari hasil nilai siswa yang masih rendah yaitu berada dibawah Kriteria Ketuntasan Minimal (KKM) yang ditetapkan yaitu 75 . Hanya $32 \%$ dari siswa yang nilai ulangannya bisa mencapai KKM yang diharapkan.

Untuk menyelesaikan kesulitan tersebut, guru mencoba mencari teknik baru dalam pembelajaran yang melibatkan siswa secara aktif, merancang kegiatan pembelajaran yang mampu mengembangkan berbagai kompetensi, baik dalam ranah kognitif, ranah afektif maupun ranah psikomotorik siswa. Salah satu alternatifnya adalah dengan memberikan kegiatan eksperimen dalam pembelajaran. Kegiatan eksperimen dipilih karena diharapkan akan mampu memotivasi siswa untuk belajar aktif dan memudahkan siswa dalam memahami materi pembelajaran sehingga hasil nilai siswa juga akan meningkat

Menurut Roestiyah (2008:80) menyatakan bahwa metode eksperimen adalah salah satu cara mengajar, dimana siswa melakukan percobaan tentang suatu hal, mengamati prosesnya serta melukiskan hasil percobaannya, kemudian hasil pengamatan itu disampaikan ke kelas dan dievaluasi oleh guru. Dengan tujuan agar siswa mampu mencari dan menemukan sendiri berbagai jawaban atas persoalan-persoalan yang dihadapinya dengan mengadakan percobaan sendiri, dilatih dalam cara berpikir yang ilmiah (scientific thinking) untuk menemukan bukti kebenaran dari sesuatu teori yang dipelajari. Penggunaan metode yang sesuai dalam menyampaikan materi pelajaran sangat berpengaruh terhadap hasil belajar. Menurut Sri Anitah W, dkk (2010:2.19)"Hasil belajar merupakan kulminasi dari suatu proses yang telah dilakukan dalam belajar. Hasil belajar harus menunjukkan suatu perubahan tingkah laku atau perolehan perilaku yang baru dari siswa yang bersifat menetap, fungsional, positif, dan disadari”.

Motivasi belajar adalah kondisi psikis yang mendorong seseorang untuk melakukan sesuatu, yang berarti pula mendorong seseorang untuk belajar. Motivasi juga berarti keseluruhan prestasi atau daya penggerak dalam diri individu yang menimbulkan kegiatan belajar dan menjamin kelangsungan belajar(Winkel,1984: 45). Dengan adanya motivasi, siswa akan senantiasa semangat untuk belajar tanpa adanya paksaan dari pihak manapun. Untuk menumbuhkan motivasi pada siswa tentunya bukan perkara mudah karena setiap siswa memiliki karakter dan keinginan yang berbeda-beda. Hal ini memang tidak sepenuhnya menjadi tanggung jawab guru, namun kita sebagai seorang guru memilikik peranan penting di dalamnya, karena sering kali para siswa belum memahami untuk apa ia belajar materi yang 
diberikan oleh sekolah. Oleh sebab itu motivasi guru sangat diperlukan untuk membangkitkan semangat siswa agar mau dan ingin belajar.

\section{METODE PENELITIAN}

Penelitian ini dilaksanakan dengan rancangan penelitian tindakan kelas dengan prosedur pelaksanaannya mengikuti prinsip dasar penelitian tindakan yang umum. Adapun Langkahlangkah penelitian tindakan kelas terdiri dari tahap perencanaan, pelaksanaan tindakan, observasi dan refleksi. Penelitian ini dilakukan sebanyak dua siklus. Siklus pertama dilakukan dalam 2 kali kegiatan pembelajaran dan siklus kedua 2 kali kegiatan pembelajaran. Kegiatan perencanaan diawali dengan mengembangkan silabus, menyusun Rencana Pelaksanaan Pembelajaran(RPP), menyiapkan peralatan untuk melakukan eksperimen, membuat petunjuk kerja berupa lembar kerja siswa serta menyusun instrumen pengamatan. Adapun instrumen penelitian yang disiapkan antara lain: (1) Lembar observasi tentang tindakan guru, (2) Lembar observasi motivasi/keaktifan siswa, (3) Lembar penilaian atau rubrik penilaian hasil belajar siswa, (4) Angket siswa, (5) Dokumentasi

Indikator keberhasilan tindakan yang dilakukan guru selama penelitian dengan penerapan kegiatan eksperimen adalah jika 100\% siswa dalam kelas aktif mengikuti kegiatan pembelajaran (aktif merangkai alat dan bahan, aktif melaksanakan eksperimen, aktif bertanya, aktif menjawab pertanyaan) dan sekurang-kurangnya $75 \%$ dari siswa mendapatkan nilai sesuai dengan KKM yang ditetapkan sekolah yaitu 75. Adapun pengumpulan data dilakukan pada setiap siklus mulai dari awal sampai akhir tindakan siklus I sampai II. Pengumpulan data dilakukan dengan menggunakan beberapa instrumen yang telah disiapkan.

Subyek penelitian ini adalah siswa SMPN 1 Sugihwaras kelas VIII C tahun pelajaran 2019/2020 yang berjumlah 32 siswa, terdiri dari 16 anak laki-laki dan 16 anak perempuan. Analisis data dilakukan dengan mendiskripsikan data dari hasil pengamatan dan angket menjadi data kualitatif. Data tersebut meliputi 4 hal, yaitu data hasil pengamatan tentang kemampuan guru menerapkan kegiatan ekeperimen dalam pengajaran, aktifitas/motivasi siswa, data hasil penilaian belajar siswa terhadap materi pembelajaran, dan data tentang respon siswa terhadap kegiatan pembelajaran. Analisis data dilakukan secara simultan, sejak dilaksanakannya siklus I sampai terakhir.

\section{HASIL DAN PEMBAHASAN}

\section{Hasil}

\section{Hasil Observasi Aktivitas Siswa dalam Kegiatan Belajar Mengajar (KBM)}

Hasil observasi diperoleh dari lembar observasi yang dilakukan oleh peneliti dan juga anggota tim lainnya terhadap aktivitas siswa dalam Kegiatan Belajar Mengajar selama 2 siklus. Data hasil observasi tertera dalam tabel berikut:

Tabel 1. Hasil Observasi Aktivitas Siswa Dalam Pembelajaran

\begin{tabular}{clcccc}
\hline & \multicolumn{2}{c}{ Aspek yang } & \multicolumn{2}{c}{ Presentase aktivitas siswa setiap siklus } \\
No. & $\begin{array}{c}\text { Siamati } \\
\text { Siklus I (\%) }\end{array}$ & Jumlah & \% & Jumlah & \% \\
\hline 1. & $\begin{array}{l}\text { Memperhatikan } \\
\text { penjelasan guru }\end{array}$ & 18 & 56.25 & 29 & 90.62 \\
2. & $\begin{array}{l}\text { Menyampaikan } \\
\text { tanggapan }\end{array}$ & 20 & 62.50 & 31 & 96.88 \\
3. & $\begin{array}{l}\text { Menyimpulkan } \\
\text { materi pelajaran }\end{array}$ & 17 & 53.13 & 23 & 71.88 \\
4. & $\begin{array}{l}\text { Perilaku yang tidak } \\
\text { relevan }\end{array}$ & 5 & 15.63 & 1 & 3.13 \\
\hline
\end{tabular}




\section{Hasil Observasi Kemampuan Guru dalam Kegiatan Belajar Mengajar}

Observasi dilaksanakan oleh rekan guru IPA lain yang berperan sebagai pengamat, dengan menggunakan lembar observasi terhadap guru dalam KBM selama 2 siklus. Adapun data hasil observasi adalah sebagai berikut:

Tabel 2. Skor Kemampuan Guru dalam KBM

\begin{tabular}{clcc}
\hline \multirow{2}{*}{ No } & \multirow{2}{*}{ Aspek yang diamati } & \multicolumn{2}{c}{ Skor pengamatan setiap siklus } \\
& & Siklus I & Siklus II \\
\hline 1 & Pendahuluan & 3,40 & 4,00 \\
2 & Kegiatan Inti & 3,75 & 4,25 \\
3 & Penutup & 2,75 & 3,75 \\
4 & Keadaan Kelas & 2,70 & 3,75 \\
& & & \\
Rata-Rata Skor Setiap Siklus & 3.15 & 3.94 \\
\hline
\end{tabular}

\section{Hasil Belajar Siswa Tentang Pemahaman dan Penguasaan Konsep}

Hasil belajar siswa tentang pemahaman dan penguasaan konsep yang diperoleh dari tes setiap siklusnya dapat dilihat pada tabel berikut:

Tabel 3. Hasil Belajar Siswa Tiap Siklus

\begin{tabular}{clcc}
\hline \multirow{2}{*}{ No } & \multirow{2}{*}{ Aspek } & \multicolumn{2}{c}{ Ketuntasan } \\
& & Tuntas $(\%)$ & Tidak tuntas $(\%)$ \\
\hline 1 & Siklus I & 59.37 & 40.63 \\
2 & Siklus II & 78.13 & 21.87 \\
\hline
\end{tabular}

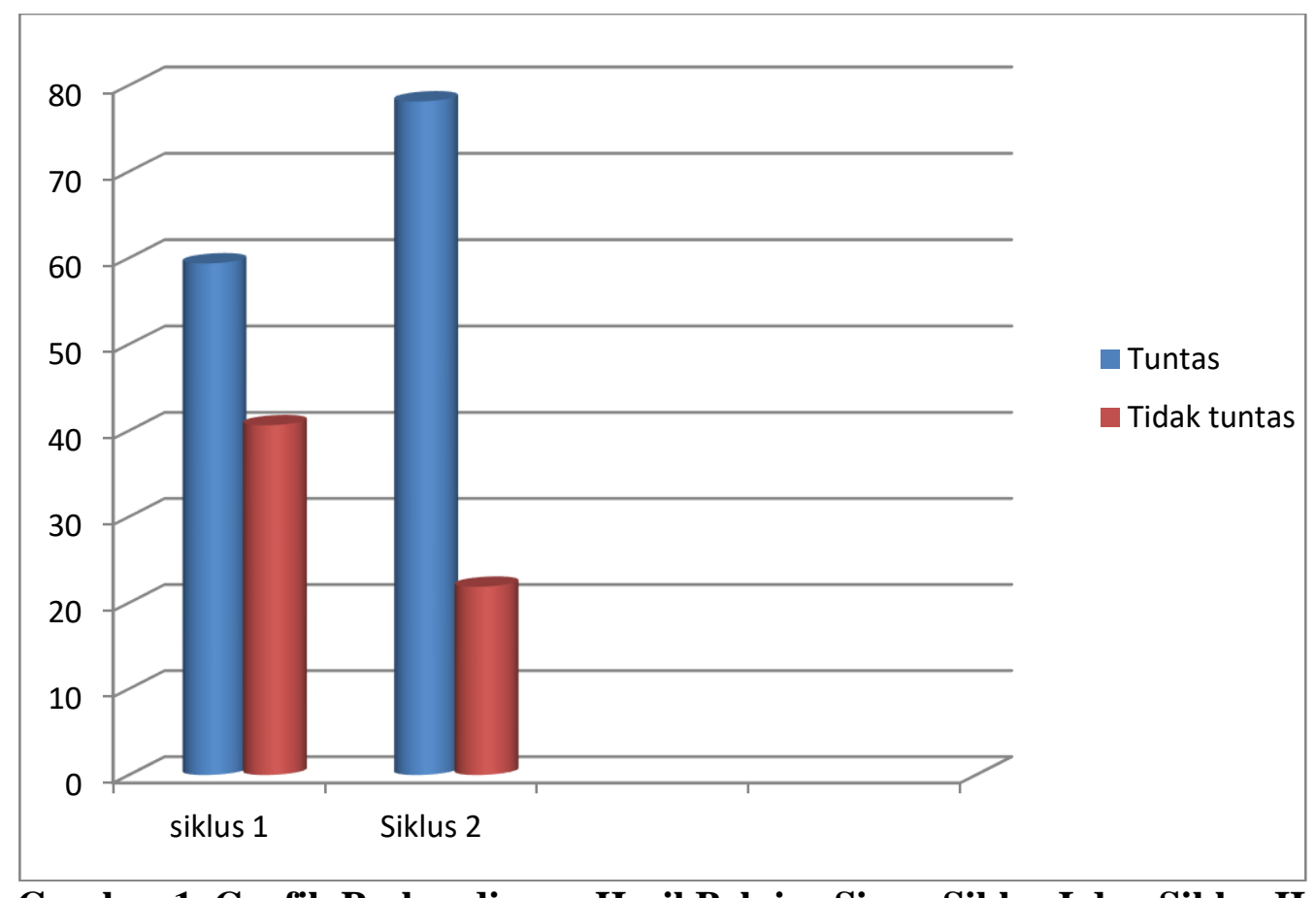

Gambar 1. Grafik Perbandingan Hasil Belajar Siswa Siklus I dan Siklus II

\section{Respon Siswa Terhadap Kegiatan Belajar Mengajar}

Data respon siswa dikumpulkan dengan menyebarkan angket kepada siswa. Hasilnya seperti yang tertera pada tabel berikut: 
Vol 1. No. 4, Oktober 2021 P-ISSN : 2774-8030, e-ISSN : 2774-8030

Tabel 4. Data Persentase Respon Siswa Terhadap Kegiatan Pembelajaran

\begin{tabular}{|c|c|c|c|c|c|}
\hline \multirow[t]{2}{*}{ No } & \multirow[t]{2}{*}{ Respon Siswa } & \multicolumn{2}{|c|}{ Siklus I } & \multicolumn{2}{|c|}{ Siklus II } \\
\hline & & Jumlah & Prosentase & Jumlah & Prosentase \\
\hline 1. & $\begin{array}{l}\text { Siswa yang menyatakan bahwa } \\
\text { eksperimen dalam pembelajaran } \\
\text { menarik }\end{array}$ & 32 & $100 \%$ & 15 & $46.87 \%$ \\
\hline 2. & $\begin{array}{l}\text { Siswa yang menyatakan } \\
\text { eksperimen dalam pembelajaran } \\
\text { menyenangkan }\end{array}$ & 29 & $90.63 \%$ & 30 & $93.75 \%$ \\
\hline 3. & $\begin{array}{l}\text { Siswa yang menyatakan bahwa } \\
\text { dengan eksperimen, materi lebih } \\
\text { mudah dipahami }\end{array}$ & 31 & $96.88 \%$ & 30 & $93.75 \%$ \\
\hline 4. & $\begin{array}{l}\text { Siswa yang menyatakan bahwa } \\
\text { dengan eksperimen, guru bisa } \\
\text { menjadi fasilitator. }\end{array}$ & 31 & $96.88 \%$ & 29 & $90.63 \%$ \\
\hline 5. & $\begin{array}{l}\text { Siswa yang menyatakan } \\
\text { eksperimen dalam pembelajaran } \\
\text { perlu dilakukan }\end{array}$ & 30 & $93.75 \%$ & 30 & $93.75 \%$ \\
\hline 6. & $\begin{array}{l}\text { Siswa yang menyatakan dengan } \\
\text { eksperimen dalam pembelajaran } \\
\text { menjadi lebih aktif dan } \\
\text { bersemangat dalam mengikuti } \\
\text { kegiatan belajar. }\end{array}$ & 29 & $90.63 \%$ & 32 & $100 \%$ \\
\hline
\end{tabular}

\section{Pembahasan}

\section{Hasil Observasi Aktivitas Siswa dalam Kegiatan Belajar Mengajar}

Berdasarkan data tabel 1 tampak bahwa aktivitas siswa dalam Kegiatan Belajar Mengajar secara keseluruhan dari siklus I ke siklus II mengalami kemajuan. Pada aspek perhatian siswa terhadap penjelasan guru di siklus I terdapat $56,25 \%$ dan di siklus II terdapat $90,62 \%$. Terdapat $62,50 \%$ siswa yang aktif memberi jawaban terhadap soal-soal materi di siklus I, dan di siklus II menjadi 96,88\%. Terdapat 53,13\% siswa yang menyimpulkan materi pelajaran pada siklus I, dan naik di siklus II menjadi 71,88\%. Hal ini disebabkan pada siklus I siswa masih disibukkan dengan keingintahuan terhadap eksperimen yang akan dilakukan. Perhatian siswa terpusat pada alat dan bahan atau persiapan yang akan dilakukan dalam eksperimen sehingga siswa kurang memperhatikan penjelasan yang diberikan guru. Kondisi ini masih terbawa saat kegiatan berlangsung, ada beberapa siswa yang tidak menjawab pertanyaan yang sudah menjadi bagiannya, sehingga harus dijawab oleh teman yang lain. Tetapi di siklus II siswa sudah mulai terbiasa dengan kegiatan tersebut dan mulai menyadari pentingnya penjelasan guru sebelum kegiatan eksperimen, juga mulai berani untuk memberikan jawaban terhadap pertanyaan-pertanyaan yang diberikan dalam pembelajaran dan merasa perlu untuk menyimpulkan materi pelajaran yang didiskusikan.

Selain itu ada beberapa siswa yang berperilaku tidak relevan dalam kegiatan belajar mengajar, pada siklus I terdapat 5 siswa, hal ini dapat diatasi oleh guru dengan cara selalu memberi kesempatan siswa-siswa tersebut untuk memberikan tanggapan terhadap pertanyaan yang sudah dijawab oleh temannya. Sehingga siswa tersebut akan berusaha untuk aktif dan perilaku siswa tersebut tidak terulang pada siklus II. Tetapi pada siklus II masih terdapat 1 siswa yang masih berperilaku tidak relevan. Siswa tersebut mengikuti kegiatan pembelajaran tetapi kurang fokus dan sering membuat ulah sendiri.

Penerapan kegiatan eksperimen ini berupaya untuk membangkitkan motivasi, minat dan perhatian siswa dalam pembelajaran dengan mengubah sikap siswa yang semula kurang aktif untuk menjadi aktif, sehingga nampak perilaku siswa yang belajar dengan penuh semangat, dan menyenangkan. Menurut Musfiqon (2012:8), hasil belajar siswa dipengaruhi oleh dua faktor 
utama, yakni faktor dari dalam diri siswa (internal faktor) dan faktor yang datang dari luar diri siswa (external factor). Faktor dari dalam diri siswa berkaitan dengan kemampuan yang dimiliki siswa. Faktor ini sangat besar pengaruhnya terhadap hasil belajar yang akan dicapai. Selain faktor kemampuan, ada juga faktor lain yang mempengaruhi seperti motivasi, minat, perhatian, sikap, kebiasaan belajar, ketekunan, kondisi sosial ekonomi, kondisi psikis dan fisik.

\section{Hasil Observasi Kemampuan Guru dalam Kegiatan Belajar Mengajar}

Berdasarkan tabel 2 tentang perolehan skor kemampuan guru dalam Kegiatan Belajar Mengajar menunjukkan bahwa dari 4 aspek yang diamati, yaitu pendahuluan, kegiatan inti, penutup dan pengelolaan guru dalam kelas mengalami peningkatan dari siklus I ke siklus II. Hal ini juga menunjukkan bahwa guru telah melakukan pengajaran sesuai dengan sintak-sintak yang direncanakan. Guru berusaha untuk melakukan perbaikan dalam pengajarannya. Pada siklus I guru masih agak kesulitan dalam membimbing siswa yang belum terbiasa dengan penerapan kegiatan eksperimen. Guru juga kurang maksimal dalam mengelola kelas maupun waktu belajar, sehingga suasana belajar kurang kondusif. Pada siklus II guru melakukan perbaikan, baik dalam pembentukan kelompok maupun dalam pembimbingan. Pembimbingan dilakukan lebih intensif dan jumlah kelompok diperbanyak dari 6 kelompok menjadi 8 kelompok belajar, sehingga anggota tiap kelompok lebih sedikit. Dengan perubahan kelompok tersebut mampu menciptakan suasana belajar yang lebih kondusif, efektif dan menyenangkan, serta siswa lebih nyaman dalam melakukan eksperimen karena tidak terlalu ramai dalam kelompoknya.

Salah satu keberhasilan belajar siswa dipengaruhi oleh faktor dari dalam siswa itu sendiri, selain itu peran besar guru juga sangat berpengaruh terhadap keberhasilan belajar siswa. Menurut Musfiqon (2012: 9), faktor kualitas pengajaran, khususnya kompetensi guru terhadap hasil belajar siswa telah ditunjukkan oleh hasil penelitian. Salah satu diantaranya penelitian Nana Sudjana (1984) di bidang Pendidikan Kependudukan. Hasil penelitian tersebut menunjukkan bahwa 76,6\% hasil belajar siswa dipengaruhi oleh kompetensi guru, dengan rincian kemampuan guru mengajar memberikan sumbangan $32,43 \%$, penguasaan materi pelajaran memberikan sumbangan $32,58 \%$ dan sikap guru terhadap mata pelajaran memberikan sumbangan $8,60 \%$

\section{Hasil Belajar Siswa Tentang Pemahaman dan Penguasaan Konsep}

Berdasar tabel 3 menunjukkan bahwa hasil tes pemahaman terhadap materi pelajaran pada siklus I hanya mencapai 59,37\% yang memperoleh nilai di atas KKM, yaitu 75. Ini berarti indikator keberhasilan siswa (penelitian) belum tercapai. Hal ini kemungkinan disebabkan siswa masih beradaptasi terhadap penerapan kegiatan eksperimen dalam pembelajaran, sehingga masih agak kesulitan dalam memahami materi pelajaran, mereka masih disibukkan dengan lat dan bahan atau persiapan eksperimen. Selain itu juga pada siklus ini kelompok belajarnya terlalu besar, sehingga dengan anggota kelompok yang terlalu banyak mengurangi konsentrasi siswa dalam memahami materi pelajaran.

Pada siklus II, pencapaian hasil belajar tentang pemahaman terhadap materi pelajaran mengalami peningkatan, yaitu 78,13\% siswa memperoleh nilai di atas 75, yang berarti indikator keberhasilan siswa terhadap materi pelajaran bisa tercapai. Berdasarkan uraian tersebut, maka dapat dikatakan bahwa "penerapan kegiatan eksperimen dapat meningkatkan motivasi sehingga meningkat pula hasil belajar siswa kelas VIII-C SMP Negeri 1 sugihwaras Kabupaten Bojonegoro".

Menurut Prosser (1999:11), pembelajaran yang baik adalah pembelajaran yang membawa anak didik pada pemahaman. Hal ini didukung data pada tabel 4 tentang respon siswa terhadap Kegiatan Belajar Mengajar yang diperoleh dari pemberian angket pada siswa. Dari data tersebut tampak bahwa pada siklus I maupun siklus II sebagian besar siswa menyatakan pembelajaran dengan penerapan kegiatan eksperimen sangat menarik dan menyenangkan sehingga meningkatkan motivasi mereka untuk lebih aktif dalam belajar. Sebagian besar siswa 
juga menyatakan dengan eksperimen maka materi pelajaran akan lebih mudah dipahami, , sehingga mereka menginginkan agar metode eksperimen sering dilakukan dalam pembelajaran IPA.

\section{KESIMPULAN}

Berdasarkan hasil dan pembahasan maka dapat disimpulkan bahwa penerapan kegiatan eksperimen dapat meningkatkan motivasi sehingga meningkat pula hasil belajar siswa kelas VIII C SMP Negeri 1 Sugihwaras Kabupaten Bojonegoro. Berdasarkan hasil survei respon siswa terhadap pembelajaran, agar metode eksperimen sering dilakukan pada pembelajaran IPA sehingga pembelajaran akan lebih menarik dan menyenangkan.

\section{DAFTAR PUSTAKA}

Angkowo R dan A. Kosasih. (2007). Optimalisasi Media Pembelajaran. Jakarta: PT. Grasindo Anitah, Sri.W., dkk. (2010). Strategi Pembelajaran di SD. Jakarta: Universitas Terbuka

BSNP. (2006). Standar Isi untuk Satuan Pendidikan Dasar dan Menengah. Jakarta: Depdiknas. Musfiqon. (2012). Pengembangan Media dan Sumber Pembelajaran. Jakarta: PT Prestasi Pustakaraya

Prosser, Michael and Keith Trigwell. (1999). Understanding Learning and Teaching. Philadelphia: Open University.

Roestiyah N.K. (2008). Strategi Belajar Mengajar. Jakarta: Rineka Cipta.

Sutiah. (2020). Pengembangan Pembelajaran Hybrid Learning. https://www.google.co.id/books/edition/PENGEMBANGAN_PEMBELAJARAN_HY BRID_LEARNIN/iqXsDwAAQBAJ?hl=id\&gbpv=1\&dq=Nana+Sudjana+bidang+pend idikan+kependuduk

Winkel. (1984). Psikologi Pendidikan dan Evaluasi Belajar. Jakarta: Gramedia 